International Journal of Life Sciences
Available online at http://sciencescholar.us/journal/index.php/ijls
Vol. 2 No. 3, December 2018, pages: $28 \sim 37$
e-ISSN: 2550-6986, p-ISSN: 2550-6994
https://doi.org/10.29332/ijls.v2n3.201

\title{
Bird Pest Attack and Sound Characteristics of Bamboo Traditional Instruments as Bird Pest Repellent on Rice Fields in Bali
}

\author{
(1) cosshank \\ I Gde Antha Kasmawan a, I Wayan Supartha b , I Nyoman Wijaya c, Ida Ayu Dwi Giriantari d
}

Article history: Received 20 July 2018, Accepted: 30 August 2018, Published: 2 October 2018

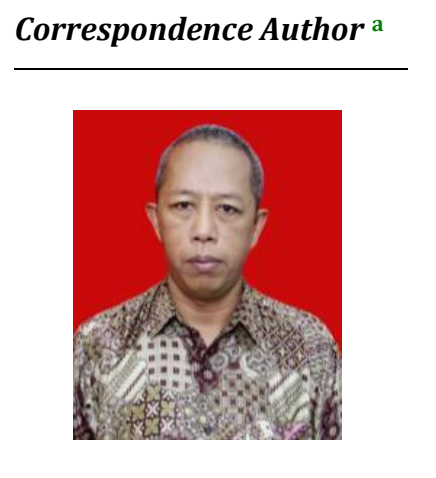

Keywords

Bamboo traditional instruments;

Bird pest attack;

Bird pest repellent;

Rice fields;

Sound characteristics;

\section{Abstract}

The purpose of this study was to observe the attack of bird pest and examine Balinese bamboo traditional instruments, (in local language called kepuakan), as a repellent of bird pest. The research method used is the survey method, sample testing, or a combination of both. For bird pest attack, the survey results show that damage in rice panicles can reach $75 \%$ more. For kepuakan, the results of the survey and testing of the kepuakan samples in three rice planting centers, namely Tabanan, Badung, and Gianyar regencies, showed that kepuakan was made of bamboo rope (Giganlochloa apus) and jajang bamboo (Giganlochloa ridleyi) with various dimensions, length from 39.0-75.2 cm, diameter from 4.7-6.6 cm, thick bamboo from 0.4-0.8 cm. Sound characteristics produced by kepuakan are similar to knocking sound with the maximum sound pressure level varies from 101-112 $\mathrm{dB}$ at $10 \mathrm{~cm}$ distance and with frequency interval between $509-1,889 \mathrm{~Hz}$ with an average frequency of 1,205 $\mathrm{Hz}$ which is still within the range of hearing of birds. Based on the results of the characteristic test, the instrument of kepuakan is still feasible and safe to use as bird pest repellent on rice fields.

e-ISSN: 2550-6986, p-ISSN: 2550-6994 (c) Copyright 2018. The Author. SS Journals Published by Universidad Técnica de Manabí. This is an open-access article under the CC BY-SA 4.0 license (https://creativecommons.org/licenses/by-sa/4.0/) All rights reserved.

\section{Contents}

Abstract.

a Department of Physics, Faculty of Mathematics and Natural Sciences, Udayana University, Indonesia

b Department of Agroecotechnology, Faculty of Agriculture, Udayana University, Indonesia

c Department of Agroecotechnology, Faculty of Agriculture, Udayana University, Indonesia

d Department of Electrical Engineering, Faculty of Engineering, Udayana University, Indonesia 
2. Materials and Methods.

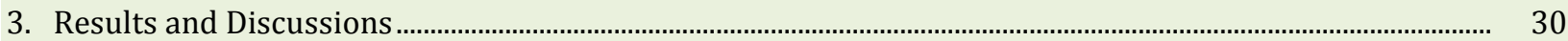

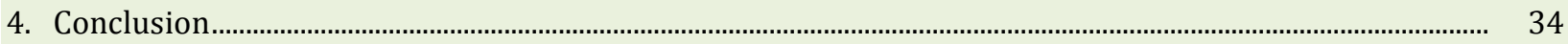

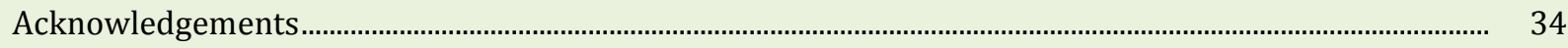

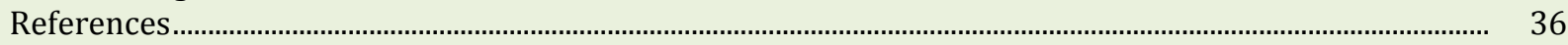

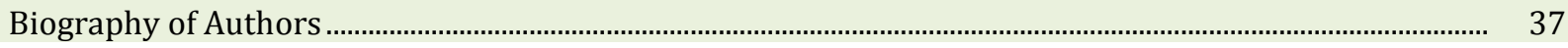

\section{Introduction}

In Indonesia, especially in Bali, the existence of rice-eating birds, which in the local language is called bondol (Lonchura sp.) is easily found especially in rice fields, ie when rice crops begin to enter the generative phase. Rice fields are one of the living habitats favored by these bird species in addition to other bush habitats (Ayat, 2011). When the population is economically less profitable, the presence of these birds will emerge as the main pest of rice plants.

Bird control can generally be done in several ways, namely by simultaneous planting, direct capture by nets, closing the entire surface of the rice plant using $1 \mathrm{~cm}^{2}$ perforated net from strong and light materials such as nylon thread, or scaring birds audio-visual. Visually, birds can be feared using scarecrows (ribbons), ribbons, fake eagles, balloons, lights, flags, and plastic tassel. In audio, the use of various sound instruments that are commonly used, such as traditional instruments made of bamboo, used cans, cannons, and electronic devices (Brittingham, 2015). The choice of an audio instrument is very possible because it is based on the consideration that the best way birds communicate is by sound through the auditory canal (Waldvogel, 2000). For the area of Bali, Indonesia, the use of an acoustic instrument that is still commonly used to prevent bird pest in the rice fields is a special instrument called kepuakan, which is a simple sound instrument made from local bamboo materials. Meanwhile, control of birds in rice fields using pesticides is still difficult to do and the expected results are also less effective.

The ears and hearing of birds are somewhat different from humans and other mammals. Lack of auricle in birds results in lower hearing sensitivity than mammals. In birds, the transmission of vibrations from the eardrum (tympanum) to the inner ear passes through a single small bone (columella). The inner ear in the bird functions as a balance and hearing instrument. Hearing in birds takes place in the cochlea. The range of hearing frequency is determined by the length of the cochlea which is certainly different between species (Beason, 2004). This different bone structure causes birds to detect sound with a narrower frequency than mammals (Dooling and Popper 2007).

Bird hearing sensitivity is generally in the range of 1-5 kHz (Bouteloup et al, 2011 and Dooling, 2002). Each bird species has a different range of hearing sensitivity (Brumm and Slabbekoorn, 2005). Furthermore, Dooling (2002) states that the best hearing range for birds ranges from 2-4 kHz. Beason (2004) adds that although birds can hear higher and lower frequencies, the hearing of birds most sensitive to sound ranges from 1-4 kHz. Compared to the range of hearing of birds, The frequency range of bird sounds is usually located between $100 \mathrm{~Hz}$ and $8 \mathrm{kHz}$ and varies greatly for different species (Fagerlund, 2004).

Bird's hearing sensitivity can be reduced by excessive stimulation of the acoustic signal above the surrounding noise. In general, birds can immediately restore hearing sensitivity and regenerate hair cell receptors after experiencing high levels of excessive acoustic exposure. The recovery rate of bird hearing sensitivity is different among species. In noisy environments, birds exhibit behavioral responses in vocalizations by voicing (calling or singing) with a higher, louder tone, or moving to a higher location (Dooling, 2002; Beason, 2004; Bouteloup et al, 2011).

In relation to the range of frequencies that birds can hear, bird IPM (Integrated pest management) generally use audible sound frequencies. The IPM of birds using ultrasound (frequency above $20 \mathrm{kHz}$ ) cannot be done (Hamershock, 1992; Dooling, 2002; Beason, 2004). Meanwhile, the IPM of birds in the infrasound area (frequency below $20 \mathrm{~Hz}$ ) is still possible. However, the bird's hearing for infrasound and other low frequencies is problematic in determining the direction of sound coming. At these low frequencies, birds fly around in any direction can approach or avoid the source of sound (Beason, 2004).

Beason (2004) states that the use of acoustic techniques in bird IPM is intended to dispel or frighten birds and not aim to destroy birds. To maximize the effectiveness of acoustic techniques, the sounds used must be

Kasmawan, I. G. A., Supartha, I. W., Wijaya, I. N., \& Giriantari, I. A. D. (2018). Bird pest attack and sound

characteristics of bamboo traditional instruments as bird pest repellent on rice fields in Bali. International Journal of Life Sciences, 2(3), 28-37. https://doi.org/10.29332/ijls.v2n3.201 
detected, heard, and frightening for birds. For this reason, the use of impulsive acoustic sources fulfills these three criteria. The presence of impulsive sounds causes the birds to fly away from the sound source. This is because when viewed from the level of noise, stinging sounds or appearing suddenly (aperiodic sounds) are more effective in producing responses to bird suffering than chronic sounds (periodic noise). Animals are generally less responsive to sounds emitted over a long period of time and periodically (Broucek, 2014).

\section{Materials and Methods}

Research on bird pest attacks has been carried out using purposive sampling technique through questionnaires and direct interviews with farmers in three rice farming centers, namely Tabanan, Badung, and Gianyar Regencies. The results obtained are data about the level of loss of farmers due to the attack of bird pest and the bird species. Furthermore, this study has focused on rice farming areas that are considered to be most severely attacked by bird pest and the data obtained are the number of bird attacks at certain hours and the impact of attacks on rice panicles. Research on the characteristics of the traditional acoustic instrument (kepuakan) has also been carried out in the three regencies. Information about instruments has been collected through field survey methods, direct interviews, and questionnaire distribution. The total number of respondents in this study was 127 farmers from 13 villages in the three regencies. Furthermore, as many as six kepuakan instruments have been collected from each region for further testing. The results obtained are data about the type of instrument material, instrument dimensions (length, thickness, and diameter), and the acoustic parameters of the instrument (intensity and frequency) which are characteristics of the instrument. Both of these observations, both in the field and in the laboratory, were then compared and analyzed.

\section{Results and Discussions}

The survey was carried out by purposive sampling technique through distributing questionnaires and interviews directly with farmers. The total of 127 farmer respondents in the three regencies (Tabanan, Badung, and Gianyar) have been given questionnaires related to the level of losses of farmers because their rice fields were attacked by bird pests. Graphically, the survey results are shown in Figure 1.

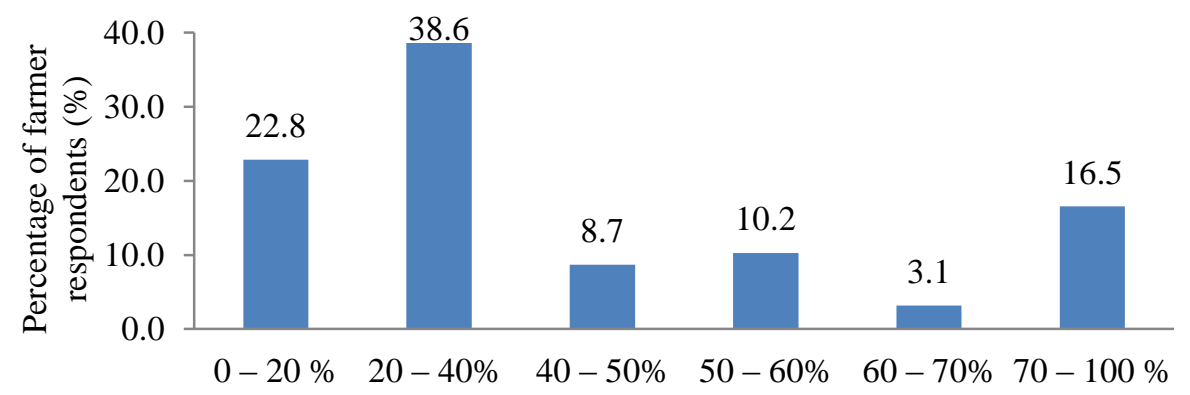

The level of loss of farmers' harvest

Figure 1. The results of the survey on the level of farmers' losses by bird pest attack.

Based on the graph, as many as $70.1 \%$ of respondents stated that the level of losses suffered ranged from 0 $50 \%$ and as many as $29.9 \%$ of respondents stated that the level of losses suffered ranged from $50-100 \%$. Based on direct interviews, the level of farmers' losses that are less than $20 \%$ is mostly due to the pattern of rice planting simultaneously or the compactness of farmers in waiting for their rice fields.

Furthermore, the study focused on rice farming areas in Temesi village (Gianyar) because according to the survey results, the areas were considered the most severely attacked by bird pests. Observation of bird pest attack is carried out on rice fields covering an area of 2,000 $\mathrm{m}^{2}$ for one hour at certain hours, ie morning (06.00-06.59 a.m.), noon (11.00-11.59 a.m.), and late evening (16.00-16.59 p.m.). Observations were carried out for three consecutive days, namely when the seeds of rice entered the mature period of milk. The results 
of these observations are shown in Figure 2. The average number of birds that attack rice plants from the highest number to the least is from 11.00-11.59 a.m. (1,151 birds), 06.00-06.59 a.m. (676 birds), and 16.0016.59 p.m. (515 birds).

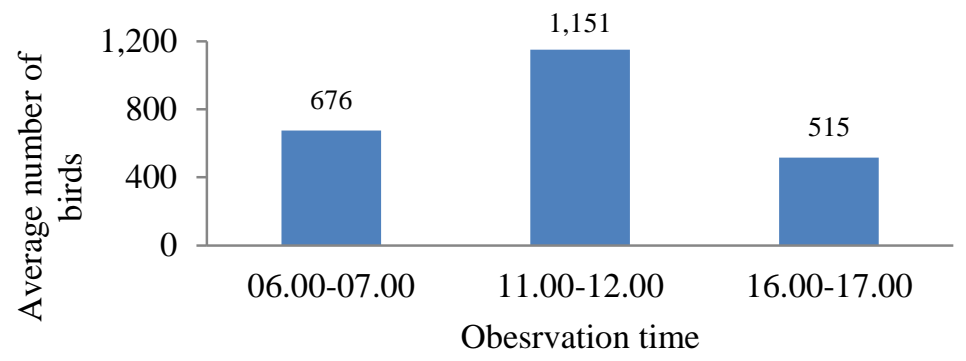

Figure 2. The average number of birds that attack rice plants for one hour at certain hours.

There are three types of birds that attack rice plants, all of them are bondol (Lonchura sp.) families, namely bondol peking (Lonchura punctulata), bondol jawa (Lonchura leucogastroides), and bondol haji (Lonchura maja). The most common species are bondol peking and the rarest is bondol haji. The bird pest attacks the rice plants from the sunrise to sunset.

The damage caused by bird attack on rice panicles is shown in Figure 3a. The rice seeds in the attacked rice panicle appear empty after the liquid of the seeds is sucked by the bird so the rice panicle does not appear to bend down because it is light. Furthermore, as many as 180 rice clumps (INPARI 33 varieties) were randomly selected and counted the number of panicles per rice clump. The calculation results show that the average number of rice panicles in one clump is 21.7 . The average number of damaged rice panicles is $78 \%$ while the intact one is $22 \%$ per rice clump (Figure $3 \mathrm{~b}$ ). Based on these results, the losses suffered by farmers can reach a range of more than $75 \%$ which of course needs to get proper treatment.

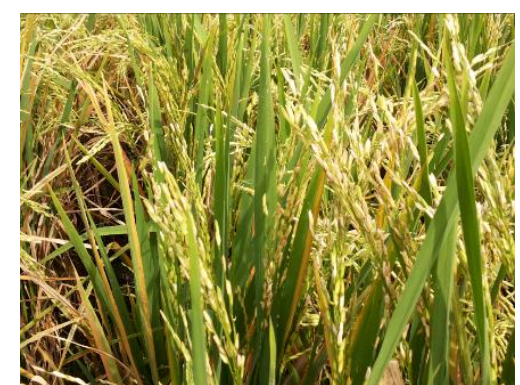

(a)

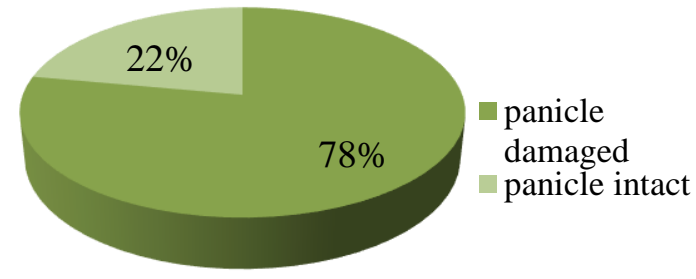

(b)

Figure 3. Damage caused by bird attack (a) seeds in rice panicles appear empty and (b) average percentage of panicle damage in rice paddies observed.

For the research on kepuakan as bird pest repellent, based on the questionnaire distributed to 127 farmer respondents related to the use of kepuakan as a repellent of bird pest in the rice field when compared to other traditional instruments, it was found that the frequency level of kepuakan use, effectiveness of kepuakan use, and comfort level of kepuakan use was $91.3 \%, 80.3 \%$, and $85.8 \%$, respectively, which is graphically shown in Figure 4. Other traditional instruments mentioned are bamboo propellers, bird whips, and a bamboo instrument which is known locally as kulkul.

Kasmawan, I. G. A., Supartha, I. W., Wijaya, I. N., \& Giriantari, I. A. D. (2018). Bird pest attack and sound characteristics of bamboo traditional instruments as bird pest repellent on rice fields in Bali. International Journal of Life Sciences, 2(3), 28-37. https://doi.org/10.29332/ijls.v2n3.201 


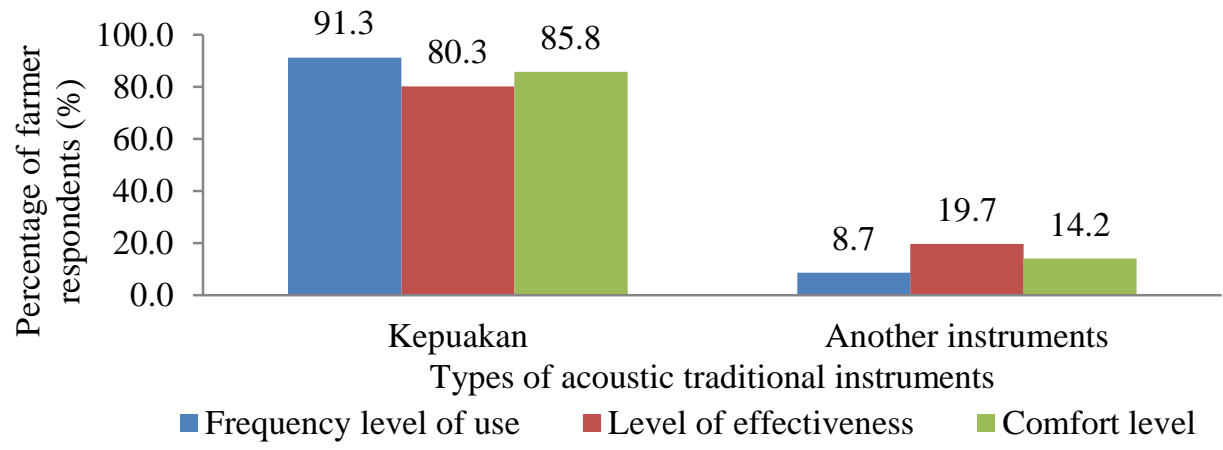

Figure 4. Graph of the use of kepuakan instrument in the three regencies surveyed.

Based on the survey results that have been conducted in three regencies, the type of bamboo material commonly used for making kepuakan instruments for the Tabanan and Badung regions is tali bamboo (Giganlochloa apus) while for Gianyar is jajang bamboo (Giganlochloa ridleyi). Measurement of kepuakan dimensions includes samples measurement of length, thickness, and diameter. The dimensions mentioned are as shown in Figure $5 \mathrm{a}$ and the form of kepuakan is shown in Figure $5 \mathrm{~b}$.

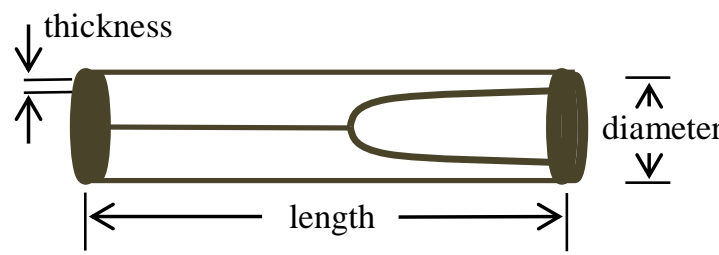

(a)

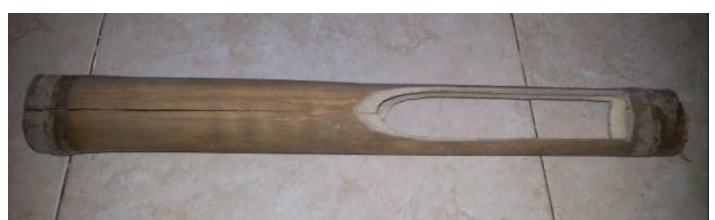

(b)

Figure 5. Balinese kepuakan instrument for bird pest repellent, (a) sketch of kepuakan dimensions, (b) a photo of a local bamboo kepuakan.

The instrument of kepuakan from Tabanan region has dimensions of length from 38.95-58.50 cm, diameter from 4.75-5.80 cm, and thickness from 0.40-0.53 cm. For kepuakan from Badung region, the length varies from 48.50-67.15 cm, diameter from 4.65-6.30 cm, and thickness from 0.40-0.78 cm. Furthermore, kepuakan from Gianyar region, its length varies from $55.60-75.20 \mathrm{~cm}$, diameter from $5.10-6.60 \mathrm{~cm}$, and thickness from 0.43-0.60 $\mathrm{cm}$. Based on these data, kepuakan from the Tabanan region has the slimmest size, where the average length, diameter, and thickness each of is $47.5 \mathrm{~cm} ; 5.49 \mathrm{~cm}$; and $0.47 \mathrm{~cm}$ when compared to the average length, diameter, and thickness of kepuakan from Badung and Gianyar regions, each of is $55.22 \mathrm{~cm}$; $5.56 \mathrm{~cm}$; and $0.53 \mathrm{~cm}$ for Badung and each of is $66.06 \mathrm{~cm} ; 5.95 \mathrm{~cm}$; and $0.53 \mathrm{~cm}$ for Gianyar, as shown in Figure 6. Based on the three graphs, it can be seen that the dimension of kepuakan is very dependent on the type of bamboo and the size of the bamboo used. Bamboo size can vary depending on the area of bamboo growth. For the same type of bamboo, on the average, the dimension of kepuakan from Badung is greater than the dimension of kepuakan from Tabanan. This is because the growth area is different, which includes the level of soil fertility, temperature, and humidity where the bamboo grows. Kepuakan from Gianyar has the largest dimensions because the type of jajang bamboo is larger than the type of tali bamboo. 


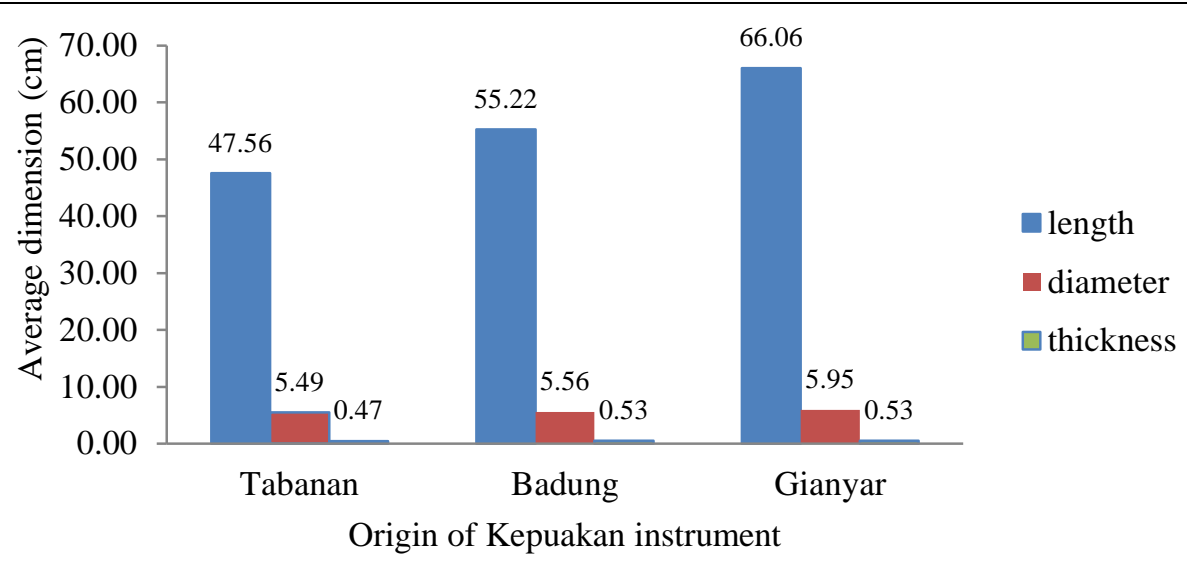

Figure 6. Graph of measurement results for the average dimension of kepuakan instruments for three regencies.

In its function as a bird pest repellent, the instrument of kepuakan is sounded by stamping it using one hand (or can also use two hands) until heard a loud knocking sound. The sound pressure level of the knocking sound produced by kepuakan has been measured using a Digital Sound Level Meter (Extech 407735) at a distance of $10 \mathrm{~cm}$. The graph of the sound pressure level measurement for the six samples of each of the three regencies is shown in Figure 7. The maximum sound pressure level that can be generated by kepuakan from the lowest level to the highest is Tabanan (101-108 dB), Badung (102-111 dB), and Gianyar (103-112), with an average each of is 104.8; 105.4 ; and $106.9 \mathrm{~dB}$. This is related to the bamboo material used and the dimensions of the instrument, where the dimensions of bamboo used for the instrument from Tabanan have a slimmer dimension than the other regions.

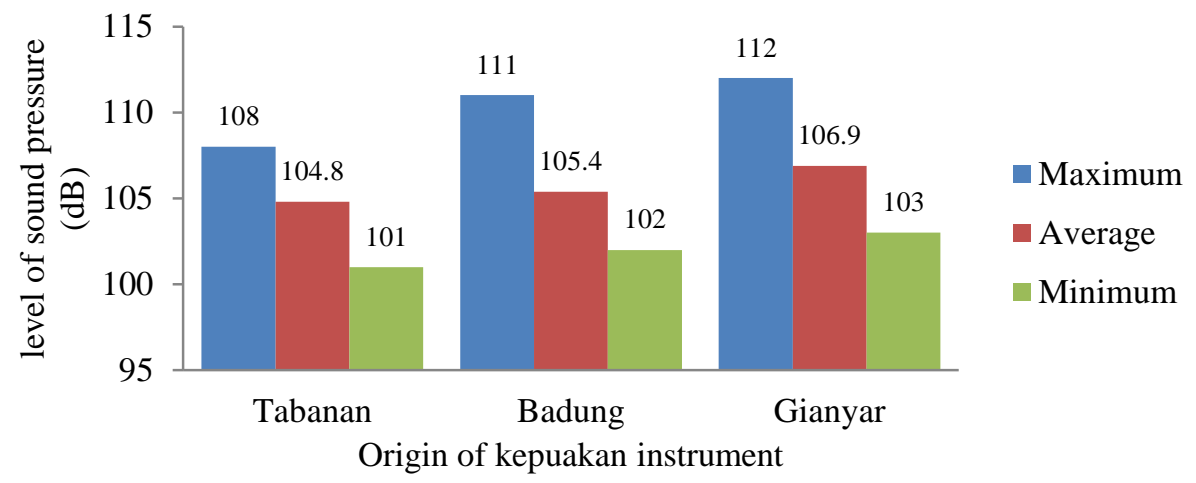

Figure 7. Graph of sound pressure level measurement results for the six samples of kepuakan each from the regions of Tabanan, Badung, and Gianyar.

In this case, the dimension of kepuakan which has a larger length and diameter can produce a greater sound pressure level. In addition, the type of bamboo used is also very influential, where the instruments from Gianyar made of jajang bamboo produce the greatest sound pressure level compared to the instruments from Tabanan and Badung which are all made from the same type of bamboo, namely tali bamboo. The instrument from Tabanan and Badung both produce almost the same sound pressure level, the difference is only $0.6 \mathrm{~dB}$ with each other.

The instrument of kepuakan that played produces a sound like a knocking sound. The sound has a compound frequency (not single) so that the measurement of kepuakan sound is done 10 times to obtain a better approach value for each kepuakan. Sound frequency measurement uses the Audio Frequency Counter android application developed by keuwsoft on Samsung Galaxy Grand Duos GT-10982 android smartphone.

Kasmawan, I. G. A., Supartha, I. W., Wijaya, I. N., \& Giriantari, I. A. D. (2018). Bird pest attack and sound characteristics of bamboo traditional instruments as bird pest repellent on rice fields in Bali. International Journal of Life Sciences, 2(3), 28-37. https://doi.org/10.29332/ijls.v2n3.201 
Overall, the graph of the average frequency measurement results of each sample of kepuakan for each origin region is shown in Figure 8.

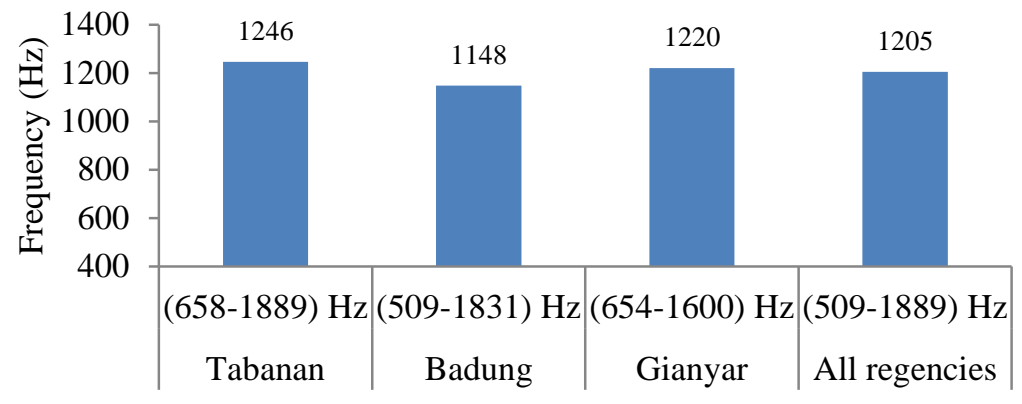

Figure 8. Graph of average frequency measurement results for each of each sample of kepuakan for each origin region.

Based on the data in Figure 8, the comparison of the average sound frequency of kepuakan for each region of origin, the instrument originating from Tabanan has the highest frequency $(1246 \mathrm{~Hz})$, followed by Gianyar $(1,220 \mathrm{~Hz})$, and Badung $(1,148 \mathrm{~Hz})$. The interval of sound frequency varies for regions from Tabanan, Badung, and Gianyar, respectively from the range $658-1,889 \mathrm{~Hz}, 509-1,831 \mathrm{~Hz}$, and $654-1,600 \mathrm{~Hz}$. The difference in the sound frequencies produced by the instrument from Tabanan and Badung is caused more by differences in instrument dimensions, while the differences between Gianyar and Badung or Tabanan are caused more by differences in the type of bamboo used. The designs of kepuakan that are shorter, thicker, and have larger diameter can produce higher sound frequencies. All of this also depends on the type of bamboo used.

Bird's hearing sensitivity is generally in the range $1-5 \mathrm{kHz}$ and the best hearing range for bird ranges from $2-4 \mathrm{kHz}$ (Bouteloup et al, 2011 and Dooling, 2002). Considering that the maximum level of sound pressure that can be produced by kepuakan in the range of $101-112 \mathrm{~dB}$ at a distance of $10 \mathrm{~cm}$ is still smaller than the threshold level of human hearing pain $(120 \mathrm{~dB})$ and with a frequency interval between $509-1,889 \mathrm{~Hz}$ with an average frequency average of $1,205 \mathrm{~Hz}$ which is still in the range of hearing of birds, then the instrument of kepuakan made of bamboo is still feasible and safe to be used to repel bird pest in rice fields. Based on the results of the survey, rice farmers still consider that the use of kepuakan is still considered effective as an instrument to repel bird pest. This is understandable given that even though acoustically, the sound of kepuakan is still below the sensitivity of the bird's hearing, but visually, birds can fly away from the rice fields because when played, the user holds the tool and occasionally brandishes the tool while walking around in the rice fields which of course the movement can frighten birds. Acoustically, the frequency of the instrument still needs to be increased to reach the level of $2 \mathrm{kHz}$ which is the lower level of the best hearing range of birds. This effort is still possible to do, namely by selecting thicker and shorter bamboo materials or by modifying in the leaves of the instrument by adding layers of metal plates.

\section{Conclusion}

The losses suffered by farmers because of bird pest attack can reach a range of more than $75 \%$ which of course needs to get proper handling, one of them is by using traditional bird pest repellents, namely kepuakan. In general, the type of bamboo material used for making kepuakan for bird pest repellent is tali bamboo and jajang bamboo with varying dimensions, length from 39.0-75.2 cm, diameter from 4.7-6.6 cm, and thickness from 0.4-0.8 $\mathrm{cm}$. The sound characteristics produced by kepuakan are similar to the sound of a knocking sound with the maximum sound pressure level varying from 101-112 dB at a distance of $10 \mathrm{~cm}$. The frequency interval produced by the instrument is in the range $509-1,889 \mathrm{~Hz}$ with an average frequency of 1,205 $\mathrm{Hz}$. So, based on these results, the instrumen of kepuakan is still feasible and safe to use to repel pests of birds in the fields. 
Acknowledgements

We are grateful to the grant-giving institutions (Udayana University, Bali-Indonesia under the supervision of Kemenristekdikti, Indonesia) in 2017, promoters and co-promoters, and also for anyone who has participated in this research.

Kasmawan, I. G. A., Supartha, I. W., Wijaya, I. N., \& Giriantari, I. A. D. (2018). Bird pest attack and sound characteristics of bamboo traditional instruments as bird pest repellent on rice fields in Bali. International Journal of Life Sciences, 2(3), 28-37. https://doi.org/10.29332/ijls.v2n3.201 


\section{References}

Ayat, A. (2010). Burung-Burung Agroforest di Sumatera. World Agroforestry Centre.

Beason, R. C. (2004). What can birds hear?. USDA National Wildlife Research Center-Staff Publications, 78.

Bouteloup, G., Clark, J., \& Petersen, D. (2011). Assessment of the Effect of Traffic Noise on Wetland Birds: Background Study for the Roe Highway Extension Project. Balcatta: Phoenix Environmental Sciences Pty Ltd., 7-12.

Brittingham, M. C. (2015). Controlling Birds on Fruit Crops. Penn State College of Agricultural Sciences, 2-3.

Brouček, J. (2014). Effect of noise on performance, stress, and behaviour of animals. Slovak J Animal Sci, 47(2), 111-23.

Brumm, H., \& Slabbekoorn, H. (2005). Acoustic communication in noise. Advances in the Study of Behavior, 35, 151-209.

Dooling, R. J. (2002). Avian hearing and the avoidance of wind turbines (pp. 1-84). Golden (CO: National Renewable Energy Laboratory.

Dooling, R. J., \& Popper, A. N. (2007). The effects of highway noise on birds. Sacramento, CA: The California Department of Transportation Division of Environmental Analysis, 74.

Fagerlund, S. (2014). Studies on bird vocaliszation detection and classification of species. Aalto University publication series: Doctoral Dissertations 166/2014, 22. Retrieved from

Hamershock, D. M. (1992). Ultrasonics as a method of bird control (No. WL-TR-92-3033). Wright lab wrightpatterson afb oh.

Waldvogel, J. A. (2000). Birdsong playback as a tool for teaching animal behavior. Tested studies for laboratory teaching, 22(22), 247-260. 


\section{Biography of Authors}

\begin{tabular}{|c|c|}
\hline & $\begin{array}{l}\text { I Gde Antha Kasmawan, S.Si., M.Sc. obtained his bachelor's degree in Physics, } \\
\text { Faculty of Mathematics and Natural Sciences, Airlangga University, Surabaya- } \\
\text { Indonesia in } 1993 \text { and obtained a master's degree in Physics at the Bandung } \\
\text { Institute of Technology, Bandung-Indonesia in 2000. Since } 1994 \text { he has been a } \\
\text { lecturer in the Department of Physics, Faculty of Mathematics and Natural } \\
\text { Sciences, Udayana University, Bali-Indonesia and currently taking the Doctor of } \\
\text { Agriculture (S3) Program, Faculty of Agriculture, Udayana University, Bali- } \\
\text { Indonesia. } \\
\text { Email:gdeanthakas@yahoo.com }\end{array}$ \\
\hline & $\begin{array}{l}\text { Prof. Dr. Ir. I Wayan Supartha, MS. obtained a bachelor's degree in Agricultural } \\
\text { Engineering, Faculty of Agriculture, Udayana University, Bali-Indonesia in } 1982 \\
\text { and obtained a master's degree in Agricultural Entomology at the Bogor } \\
\text { Agricultural Institute, Bogor-Indonesia in 1991. In } 1998 \text { he obtained a doctorate at } \\
\text { Bogor Agricultural University, Bogor- Indonesia in the field of Agricultural } \\
\text { Entomology with research topics: Bionomic of Liriomyza huidobrensis (Blanchard) } \\
\text { (Diptera: Agromyzidae) on Potato. He is currently a professor in Agriculture and } \\
\text { as Head of the Integrated Pest Management Laboratory (IPM Lab), Faculty of } \\
\text { Agriculture, Udayana University, Bali-Indonesia. } \\
\text { Email:yansupartha@yahoo.com }\end{array}$ \\
\hline & $\begin{array}{l}\text { Prof. Dr. Ir. I Nyoman Wijaya, MS. obtained a bachelor's degree in Agricultural } \\
\text { Technology, Faculty of Agriculture, Udayana University, Bali-Indonesia in } 1983 \\
\text { and obtained a master's degree in Agricultural Entomology at the Bogor } \\
\text { Agricultural Institute, Bogor-Indonesia in 1992. In } 2003 \text { he obtained a doctorate at } \\
\text { Bogor Agricultural University, Bogor- Indonesia in the field of Agricultural } \\
\text { Entomology with the topic of research: Diaphorina Citri Kuwayama (Homoptera: } \\
\text { Psyllidae): Bioecology and its role as Vector of CVPD (Citrus Vein Phloem } \\
\text { Degeneration) in Siam Citrus Plants. He is currently a professor in the field of } \\
\text { Agriculture, Faculty of Agriculture, Udayana University, Bali-Indonesia. } \\
\text { Email: wijayainyoman1956@gmail.com }\end{array}$ \\
\hline & $\begin{array}{l}\text { Prof. Ir. Ida Ayu Dwi Giriantari, M.Eng. Sc., Ph.D. obtained a bachelor's degree in } \\
\text { Electrical Engineering, Faculty of Engineering, Udayana University, Bali-Indonesia } \\
\text { in } 1990 \text { and obtained a master's degree in Electrical Engineering at the University } \\
\text { of New South Wales, Australia in 1999. In 2003, She obtained a doctorate at the } \\
\text { University of New South Wales, Australia on a topic Research: Condition } \\
\text { Monitoring of Composite Outdoor Insulators using PD Analysis. She is currently a } \\
\text { Professor in Electric Power and Energy System, Department of Electrical } \\
\text { Engineering, Udayana University, Bali-Indonesia. } \\
\text { Email: dayu.giriantari@unud.ac.id }\end{array}$ \\
\hline
\end{tabular}

Kasmawan, I. G. A., Supartha, I. W., Wijaya, I. N., \& Giriantari, I. A. D. (2018). Bird pest attack and sound characteristics of bamboo traditional instruments as bird pest repellent on rice fields in Bali. International Journal of Life Sciences, 2(3), 28-37. https://doi.org/10.29332/ijls.v2n3.201 